\title{
Organic Matter Application Improves Posttransplant Root Growth of Three Native Woody Shrubs
}

\author{
Julie Guckenberger Price ${ }^{1,2}$ Amy N. Wright and Kenneth M. Tilt \\ Department of Horticulture, Auburn University, 101 Funchess Hall, Auburn, \\ AL 36849
}

\author{
Robert L. Boyd \\ Department of Biological Sciences, Auburn University, 101 Rouse Life \\ Science Building, Auburn, AL 36849
}

Additional index words. landscape, establishment, Morella cerifera, Myrica cerifera, wax myrtle, Illicium floridanum, Florida anise tree, Kalmia latifolia, mountain laurel

\begin{abstract}
The need for reliable planting techniques that encourage posttransplant root growth in adverse conditions has prompted research into planting above soil grade (above-grade). Container-grown Morella cerifera (L.) Small (syn. Myrica cerifera L.) (wax myrtle), Illicium floridanum Ellis (Florida anise tree), and Kalmia latifolia L. (mountain laurel) plants were planted in Horhizotrons (root observation chambers) in a greenhouse in Auburn, AL, on 1 Mar. 2006, 6 June 2006, and 3 Jan. 2007, respectively. The experiment was repeated with all three species being planted 18 June 2007. Horhizotrons contained four glass quadrants extending away from the root ball providing a nondestructive method for measuring root growth of the same plant into different rhizosphere conditions. Each quadrant was filled with a native sandy loam soil in the lower $10 \mathrm{~cm}$. The upper $10 \mathrm{~cm}$ of the quadrants were filled randomly with: 1) milled pine bark (PB); 2) peat (P); 3) cotton gin compost (CGC); or 4) more native soil with no organic matter (NOM). Horizontal root lengths (HRL, length measured parallel to the ground from the root ball to the root tip) of the five longest roots visible along each side of a quadrant were measured weekly for M. cerifera and $I$. floridanum and biweekly for $K$. latifolia. These measurements represented lateral growth and penetration of roots into surrounding substrates on transplanting. When roots of a species neared the end of the quadrant, the experiment was ended for that species. $M$. cerifera had the fastest rate of lateral root growth followed by $I$. floridanum and then by $K$. latifolia. In most cases, roots grew initially into the organic matter rather than the soil when organic matter was present. In general, HRL and root dry weight (RDW) of I. floridanum and K. latifolia were greatest in $\mathrm{PB}$ and $\mathrm{P}$, whereas for $M$. cerifera, these were greatest in $\mathrm{P}$. Differences in root growth among substrates were not as pronounced for $M$. cerifera as for the other species, perhaps as a result of its rapid increase in HRL. Increased root growth in PB and $P$ may be attributed to the ideal physical and chemical properties of these substrates. Results suggest that planting above soil grade with organic matter may increase posttransplant root growth compared with planting at grade with no organic matter.
\end{abstract}

Survival of a newly transplanted tree or shrub is dependent on the development of a root system that extends into surrounding native soil. Until this occurs, the plant must rely on the water and nutrients in the transplanted container substrate, which may be extremely limited as a result of the tendency of texture and moisture gradients to pull moisture and nutrients from the root ball into

\footnotetext{
Received for publication 4 Feb. 2008. Accepted for publication 30 Nov. 2008.

Appreciation is extended to Dodd and Dodd Native Nurseries, Semmes, AL, for plant material and Dr. Peng Zeng, Department of Mathematics and Statistics, Auburn University, Auburn, AL, for statistical counsel.

${ }^{1}$ Current address: Department of Biology, University of Alabama at Birmingham, 1530 3rd Avenue S, Birmingham, AL 35294.

${ }^{2}$ To whom reprint requests should be addressed; e-mail juliegp@uab.edu.
}

the surrounding soils (Heiskanen and Rikala, 2000).

Newly transplanted shrubs may also struggle with the specific environment into which they are planted. Normal undisturbed soils have established horizons, ample pore space and organic matter, beneficial organisms, and soil aggregates that allow air, water, and nutrients to penetrate (Perry, 1982). Urban areas, where most shrubs are planted as part of a larger landscape installation, often lack the natural topsoil, and what remains is often alkaline with high clay content. These areas may also have restricted space for root growth, poor aeration, and inadequate drainage, making them lessthan-optimal environments for root growth (Craul, 1985). Once a landscape is installed, regular maintenance procedures often remove leaves and plant waste, depriving the soil of a natural litter layer and incorporation of degrading organic matter. Applica- tion of mineral fertilizers may compensate chemically, but there may still be a lack of physical benefits and microbial life from organic matter.

A common practice intended to improve transplant success is amending the backfill of the planting hole with organic matter, but studies show inconsistent results with this technique (Day et al., 1995; Ferrini et al., 2005; Smalley and Wood, 1995; Watson et al., 1993). Planting above soil grade (abovegrade) has proven to be a very successful technique both with trees (Arnold et al., 2005) and shrubs (Wright et al., 2007). Wright et al. (2007) described a modified above-grade planting technique in which the upper $7.6 \mathrm{~cm}$ of the root ball remained above the soil surface and pine bark was mounded around the above-grade portion of the root ball, tapering from the top of the root ball down to the surrounding soil grade. More root growth occurred in shrubs planted with this technique than in those planted at grade with pine bark-amended backfill

Use of native plants in the landscape is often promoted because these species may be better suited to the soils and climate of their native region than nonnative species. Although native species may not perform well in the poor transplanting situations described here, their climatic adaptations may make them more successful than nonnatives while requiring fewer inputs of fertilizer and water (Southeast Exotic Pest Plant Council, 2008). This study intends to expand on the successful specialized above-grade planting practice of Wright et al. (2007) by experimenting with three native woody shrubs chosen for their varied native habitats and transplanting success (Dirr, 1998) and other types of organic matter chosen based on current practices and availability. Therefore, the objective of this study was to determine the effect of organic matter type on posttransplant root growth of three native landscape shrubs in simulated above-grade planting conditions.

\section{Materials and Methods}

Expt. 1. On 1 Mar. and 6 June 2006 and 3 Jan. 2007, five Morella cerifera (L.) Small (syn. Myrica cerifera L.) (wax myrtle) (11.3 L) from Moore and Davis, LLC in Shorter, $\mathrm{AL}$, five Illicium floridanum Ellis (Florida anisetree) (11.3 L) from Greene Hill Nursery, Inc. in Waverly, AL, and five seedling Kalmia latifolia L. (mountain laurel) (19 L) from Dodd and Dodd Nursery, Inc. in Semmes, $\mathrm{AL}$, respectively, were removed from their containers and placed in the center of Horhizotrons (Wright and Wright, 2004) with one plant per Horhizotron. Each Horhizotron contained four wedge-shaped quadrants (volume $3.7 \mathrm{~L}$ ), each made from two $0.3-\mathrm{cm}$ thick glass panes $(20.3 \mathrm{~cm}$ tall $\times 26.7 \mathrm{~cm}$ long $)$ extending from the root ball and meeting at a point (Fig. 1). The quadrants rested on a $0.6 \mathrm{~m}$ wide $\times 0.6 \mathrm{~m}$ wide $\times 0.3-\mathrm{cm}$ thick sheet of aluminum (with drainage holes) attached to a wooden frame made from $5.1 \times 5.1-\mathrm{cm}$ treated lumber. The entire structure was 


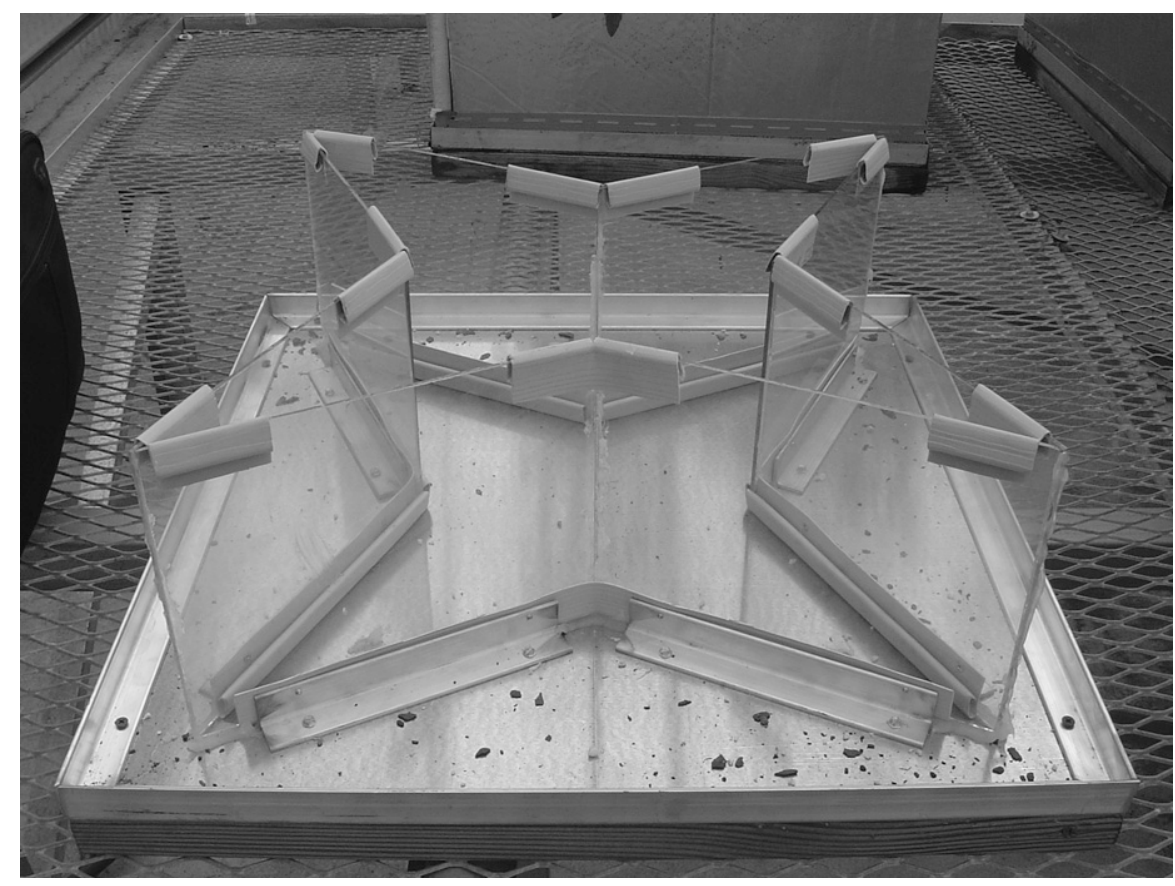

Fig. 1. The Horhizotron allows simple, nondestructive measurement through glass panes of root growth over time in a variety of rhizosphere conditions.

enclosed by a box and lid of $1.9-\mathrm{cm}$ thick foam insulation board. In each Horhizotron, the four quadrants were filled with field soil (Marvyn sandy loam) in the lower half (10 $\mathrm{cm})$. The upper half $(10 \mathrm{~cm})$ of each quadrant was then filled randomly with: 1) pine bark (PB); 2) peatmoss (P); 3) cotton gin compost (CGC); or 4) more soil with no organic matter (NOM) so that each Horhizotron had one of each of these treatments. Although this technique left the shrubs planted at grade in the Horhizotron, layering the PB, P, or CGC on top of soil was intended to simulate the modified above soil grade field planting practice in which the lower portion of the root ball is in soil and organic matter is mounded around the above-grade portion of the root ball, tapering from the top of the root ball down to the surrounding soil grade. The quadrants containing $100 \%$ soil were intended to simulate traditional at-grade planting with no organic matter. The Horhizotron allowed root growth to be observed and quantified in a greenhouse and compared with field results for the planting practice. Marvyn sandy loam is the soil type of field research plots on the campus of Auburn University in Auburn, AL, and is a typical pedon of the Marvyn Series (fine-loamy, kaolinitic, thermic Typic Kanhapludults), which are deep, well-drained, moderately permeable soils formed in loamy marine sediments on Coastal Plain uplands (Natural Resources Conservation Service, U.S. Department of Agriculture, 1997). The soil was taken from outside research plots dug from the surface to $15 \mathrm{~cm}$ deep. CGC was obtained from cotton gin trash produced by Milstead Farm Group, Inc., in Shorter, AL, and composted at E.V. Smith Research Center, also in Shorter. PB was fresh cut, chipped, and supplied by Pineywoods Mulch Company from trees grown in Roanoke, $\mathrm{AL}$, and Canadian P was supplied by Cassco, Montgomery, AL. No supplemental fertilizers were used in the substrates.

The Horhizotrons were placed on greenhouse benches at the Paterson Horticulture Greenhouse Complex, Auburn University, Auburn, AL (day/night temperatures set at $26 / 21^{\circ} \mathrm{C}$ ). Initial growth indices of plant canopies [(height + widest width + width perpendicular to widest width)/3] were measured. Root balls and quadrants were hand-watered individually as needed with tap water with all plants of one species watered at the same time. Once per week, the horizontal root lengths (HRL, measured parallel to the ground) of the five longest roots visible on each glass pane (two panes per quadrant) were recorded. HRL was measured using a transparent $1-\mathrm{cm}$ grid placed on the glass panes of each quadrant, facilitating rapid measurement. Although not actual root length, but rather lateral length, this measurement represented lateral penetration into the landscape soil and mounded organic matter after transplanting. Roots growing into soil or organic matter portions were not measured separately. All plants of a species were removed from the Horhizotrons when roots in one substrate neared the end of a quadrant $(26 \mathrm{~cm})$, and final growth indices of the canopies were measured. Plants of $M$. cerifera were removed from Horhizotrons $44 \mathrm{~d}$ after planting (DAP), I. floridanum 97 DAP, and K. latifolia 136 DAP. Roots in each quadrant were cut from the original root ball where the soil or organic matter met the root ball, and for $M$. cerifera, roots were washed to remove substrate, dried for $48 \mathrm{~h}$ at $66^{\circ} \mathrm{C}$, and weighed to determine root dry weight (RDW). For I. floridanum, on discovering the differ- ence in root growth into upper organic matter versus lower soil portions of the quadrants, roots from quadrants containing organic matter were separated into those growing into the organic matter and those growing into the soil portions at experiment termination. Keeping the roots from each portion and substrate separate, they were washed and dried to quantify RDW in soil and organic matter portions separately. As a result of the extreme difficulty of washing organic matter from the fine, hairlike roots of $K$. latifolia, a visual rating of 0 to 5 was recorded for each side of a quadrant $[0=$ no root growth; $1=10 \%$ of the quadrant was filled with roots; $2=20 \%$ of the quadrant was filled with roots; $3=30 \%$ of the quadrant was filled with roots; $4=40 \%$ of the quadrant was filled with roots; $5=50 \%$ of the quadrant was filled with roots (the most dense proliferation of $K$. latifolia roots in any substrate)] rather than washing and drying the roots. On the first and last day of the study for each species, the pourthrough nutrient extraction procedure (Wright, 1986) was used to obtain leachate samples from six 3.8-L containers of soil or each type of organic matter (without soil) to determine soil or substrate $\mathrm{pH}$ and electrical conductivity (EC) at the time of each species' experiment. These containers were filled on planting day and maintained through the duration of the experiment under the same watering regime as the substrates in the Horhizotrons. Physical properties (waterholding capacity, air space, bulk density) of organic matter substrates were determined using the NCSU Porometer $^{\mathrm{TM}}$ (Fontento et al., 1981), and chemical properties (concentrations of mineral nutrients, ammonium nitrogen, nitrate nitrogen in saturated extract) of organic matter substrates and soil were measured separately at the Auburn University Soil Testing Laboratory, Auburn, AL, by saturating the substrates with deionized water and analyzing the filtered extract.

Experimental design was a randomized complete block design with each Horhizotron forming a block and five blocks per species. Data were analyzed separately by species (because of different planting dates) using GLM procedures with mean separation within each measurement date using PDIFF at $\alpha=0.05$ as well as regression analysis of root growth over time to determine differences in root growth rates at each measurement date and over time among substrates and within each species. Significance of linear, quadratic, and cubic trends of root growth over time was investigated.

Expt. 2. In Expt. 2, all three species listed previously were planted as described previously on 18 June 2007. All procedures were the same as for Expt. 1 and at experiment termination, roots of both $M$. cerifera and I. floridanum were separated into portions from the soil and organic matter layers before washing and drying. Physical and chemical analyses of organic matter substrates and soil were not repeated; however, sources for all were the same as previously. Additionally, percent moisture by volume in each quadrant 
was measured biweekly using a Theta moisture probe and HH2 Read meter (Delta- T Devices Ltd., Cambridge, U.K.). The probe and meter were set on the standard organic setting when measuring quadrants containing organic matter and on the standard mineral setting for the $100 \%$ soil quadrants. To more accurately control substrate moisture, when percent moisture by volume fell below $10 \%$ within a quadrant, that quadrant was rewatered with $400 \mathrm{~mL}$ of tap water (the amount needed to fully hydrate the substrate in one quadrant). Plants of $M$. cerifera were removed from the Horhizotrons 43 DAP, I. floridanum 80 DAP, and K. latifolia 127 DAP. Data from all species were analyzed together because of the same planting date using GLM procedures and regression analysis of root growth over time to compare rates of root growth among species and substrates (SAS Institute, Inc., 2004). As a result of a significant interaction (species*substrate*DAP), species were then analyzed separately as in Expt. 1.

\section{Results}

Expt. 1. Horizontal root length of $M$. cerifera increased linearly in all substrates (Table 1; Fig. 2A). On the first measurement date, 21 DAP, roots in CGC and P had the greatest HRL, and this trend continued for every measurement thereafter (Fig. 2A). With the exception of the first date, when roots in CGC and P had similar HRL, roots in CGC had greater HRL than the other substrates on every measurement date (Fig. 2A). Roots in $\mathrm{P}$ had greater HRL than those in NOM and $\mathrm{PB}$ on all measurement dates (Fig. 2A). Root dry weights were similar among all substrates (Fig. 3A). Shrubs were uniform in size throughout the study with average initial growth index $84 \mathrm{~cm}$ and final $107 \mathrm{~cm}$.

I. floridanum HRL increased linearly in all substrates (Table 1; Fig. 2B). HRL of roots in $\mathrm{PB}$ and $\mathrm{P}$ was similarly greater than those in CGC and NOM from the first measurement date until 71 DAP, when HRL of roots in PB surpassed those in $\mathrm{P}$ and all other substrates (Fig. 2B). Roots in P had greater HRL than those in CGC and NOM on all measurement dates (Fig. 2B). HRL of roots in CGC and NOM was similar until 63 DAP when HRL of roots in CGC exceeded those in NOM (Fig. 2B). RDW for I. floridanum reflected HRL measurements and demonstrates that the majority of roots grew into the organic matter layers when present (Fig. 3B). Average initial growth index was $64 \mathrm{~cm}$ and final was $73 \mathrm{~cm}$ with no differences in size among shrubs.

For $K$. latifolia, HRL increased linearly in all substrates, although in CGC, limited root growth produced a low slope (Table 1; Fig. 2C). On every measurement date, HRL was greatest for roots in $\mathrm{P}$ followed closely but with lesser HRL by PB (Fig. 2C). HRL of roots in $\mathrm{P}$ and $\mathrm{PB}$ was greater than those in NOM on all measurement dates (Fig. 2C). Root visual ratings were similar to results for HRL (Table 2) with the highest visual ratings in PB and P. K. latifolia shrubs were uniform

Table 1. Expt. 1: Effect of organic matter type (treatment) on final horizontal root length (HRL $\left.{ }^{\mathrm{z}}\right)$ of $M$. cerifera, I. floridanum, and $K$. latifolia $\left(49,97\right.$, and $136 \mathrm{DAP}^{\mathrm{y}}$, respectively) growing in Horhizotrons in a greenhouse in Auburn, AL, regression equations for change in HRL over time with corresponding $R^{2}$ term and significance of regression equation ( $P$ value), and significance of treatment main effects and interactions for HRL. ${ }^{\mathrm{x}}$

\begin{tabular}{lcccr}
\hline & \multicolumn{4}{c}{ M. cerifera } \\
\cline { 2 - 5 } Treatment $^{\mathrm{w}}$ & HRL $(\mathrm{cm})$ & Equation $^{\mathrm{v}}$ & $R^{2}$ & $P$ value \\
\hline Pine bark & $20.8 \mathrm{~d}^{\mathrm{u}}$ & $\mathrm{y}=0.61 \mathrm{x}-9.36$ & 0.86 & $<0.0001$ \\
Peat & $24.1 \mathrm{~b}$ & $\mathrm{y}=0.67 \mathrm{x}-7.72$ & 0.76 & $<0.0001$ \\
Cotton gin compost & $25.2 \mathrm{a}$ & $\mathrm{y}=0.70 \mathrm{x}-7.57$ & 0.81 & $<0.0001$ \\
No organic matter & $22.9 \mathrm{c}$ & $\mathrm{y}=0.67 \mathrm{x}-11.31$ & 0.77 & $<0.0001$ \\
Significance & $P$ value & & & \\
Treatment & 0.0013 & & & \\
DAP & $<0.0001$ & & & \\
Treatment $\times$ DAP & $<0.0001$ & & & \\
\hline
\end{tabular}

\begin{tabular}{lcccr}
\hline & \multicolumn{3}{c}{ I. floridanum } \\
\cline { 2 - 5 } Treatment $^{\mathrm{q}}$ & HRL $(\mathrm{cm})$ & Equation $^{\mathrm{v}}$ & $R^{2}$ & $P$ value \\
\hline Pine bark & $22.0 \mathrm{a}$ & $\mathrm{y}=0.27 \mathrm{x}-1.82$ & 0.92 & $<0.0001$ \\
Peat & $20.1 \mathrm{~b}$ & $\mathrm{y}=0.25 \mathrm{x}-1.18$ & 0.86 & $<0.0001$ \\
Cotton gin compost & $11.3 \mathrm{c}$ & $\mathrm{y}=0.14 \mathrm{x}-0.55$ & 0.76 & $<0.0001$ \\
No organic matter & $9.0 \mathrm{~d}$ & $\mathrm{y}=0.09 \mathrm{x}+1.22$ & 0.24 & $<0.0001$ \\
Significance & $P$ value & & & \\
Treatment & $<0.0001$ & & & \\
DAP & $<0.0001$ & & & \\
Treatment $\times$ DAP & $<0.0001$ & & & \\
\end{tabular}

K. latifolia

\begin{tabular}{lcccc}
\cline { 2 - 5 } Treatment $^{\mathrm{w}}$ & HRL $(\mathrm{cm})$ & Equation $^{\mathrm{v}}$ & $R^{2}$ & $P$ value \\
\hline Pine bark & $15.9 \mathrm{~b}$ & $\mathrm{y}=0.14 \mathrm{x}-2.10$ & 0.79 & $<0.0001$ \\
Peat & $17.5 \mathrm{a}$ & $\mathrm{y}=0.12 \mathrm{x}+1.19$ & 0.81 & $<0.0001$ \\
Cotton gin compost & $1.3 \mathrm{~d}$ & $\mathrm{y}=0.01 \mathrm{x}+0.01$ & 0.06 & $<0.0001$ \\
No organic matter & $5.1 \mathrm{c}$ & $\mathrm{y}=0.04 \mathrm{x}-0.30$ & 0.14 & $<0.0001$ \\
Significance & $P$ value & & & \\
Treatment & $<0.0001$ & & & \\
DAP & $<0.0001$ & & & \\
Treatment $\times$ DAP & $<0.0001$ & & \\
\hline
\end{tabular}

${ }^{\mathrm{z}} \mathrm{HRL}=$ root length measured parallel to the ground.

${ }^{\mathrm{y} D A P}=$ days after planting in Horhizotron (Wright and Wright, 2004).

${ }^{\mathrm{x}} M$. cerifera were grown 1 Mar. to 13 Apr. 2006, I. floridanum were grown 6 June to 6 Oct. 2006, and $K$. latifolia were grown 3 Jan. to 24 May 2007.

${ }^{\text {w }}$ Treatments were soil in bottom $10 \mathrm{~cm}$ and pine bark, peat, or cotton gin compost in upper $10 \mathrm{~cm}$ or $100 \%$ soil (no organic matter) in Horhizotron quadrants.

${ }^{\mathrm{v}} \mathrm{y}=\mathrm{HRL}, \mathrm{x}=$ DAP.

"Lowercase letters denote mean separation $(\mathrm{n}=50)$ among substrates within species by PDIFF at $\alpha=0.05$ (SAS Institute, Inc., 2004).

in size with average initial growth index 86 $\mathrm{cm}$ and final $93 \mathrm{~cm}$.

EC was highest in CGC (Table 4). NOM had the highest $\mathrm{pH}, \mathrm{PB}$ and $\mathrm{CGC}$ had similar $\mathrm{pH}$, and $\mathrm{P}$ had the lowest $\mathrm{pH}$ (Table 4). CGC was the most elementally rich substrate with the highest concentration of almost every nutrient and $\mathrm{NO}_{3}$ (Table 5). CGC also had the highest waterholding capacity $(69.1 \%)$ and lowest air space (12.4\%) of the organic matter substrates. NOM had the highest bulk density $\left(1.5 \mathrm{~g} \cdot \mathrm{cm}^{-3}\right)$ and $\mathrm{PB}$ and $\mathrm{P}$ had the lowest (both 0.1 to $0.2 \mathrm{~g} \cdot \mathrm{cm}^{-3}$ ).

Expt. 2. Like in Expt. 1, HRL of both $M$. cerifera and I. floridanum increased linearly in all substrates (Table 3; Fig. 4A-B). HRL of roots in $\mathrm{P}$ was greater than all other substrates on every DAP for both species, except for the last measurement day of M. cerifera, 42 DAP, when roots in NOM and $\mathrm{P}$ had similar HRL (Fig. 4A-B). Roots of M. cerifera in $\mathrm{PB}$ and NOM had similar HRL from 15 DAP until 42 DAP, when HRL of roots in NOM was greater (Fig. 4A). I. floridanum roots in $\mathrm{PB}$ and NOM had similar HRL on the first measurement date (31 DAP), but HRL of roots in PB was greater than that in NOM on every date thereafter
(Fig. 4B). Both M. cerifera and I. floridanum roots had the least HRL in CGC on all measurement dates (Fig. 4A-B). Final RDW reflected results of HRL measurements for both species (Fig. 3C-D) in that the most RDW occurred in $\mathrm{PB}$ and P. HRL of $K$. latifolia roots in $\mathrm{PB}$ and $\mathrm{P}$ increased linearly and was greater than those in CGC and NOM on all measurement dates (Table 3; Fig. 4C). Lack of significant root growth over time of $K$. latifolia in CGC and NOM produced low slope on regression (Table 3 ). Highest visual ratings for $K$. latifolia roots were in PB and P (Table 2), similar to results for HRL. Initial and final growth indices for all three species were similar to those for Expt. 1 with uniformity within species.

\section{Discussion}

Although significance of linear, quadratic, and cubic trends of HRL increase over time, all trends were linear. In general, more root growth occurred in PB and P than in CGC or NOM regardless of experiment or species. In both experiments, lateral root extension of $M$. cerifera was faster than other species. Over all substrates, HRL for $M$. cerifera averaged 


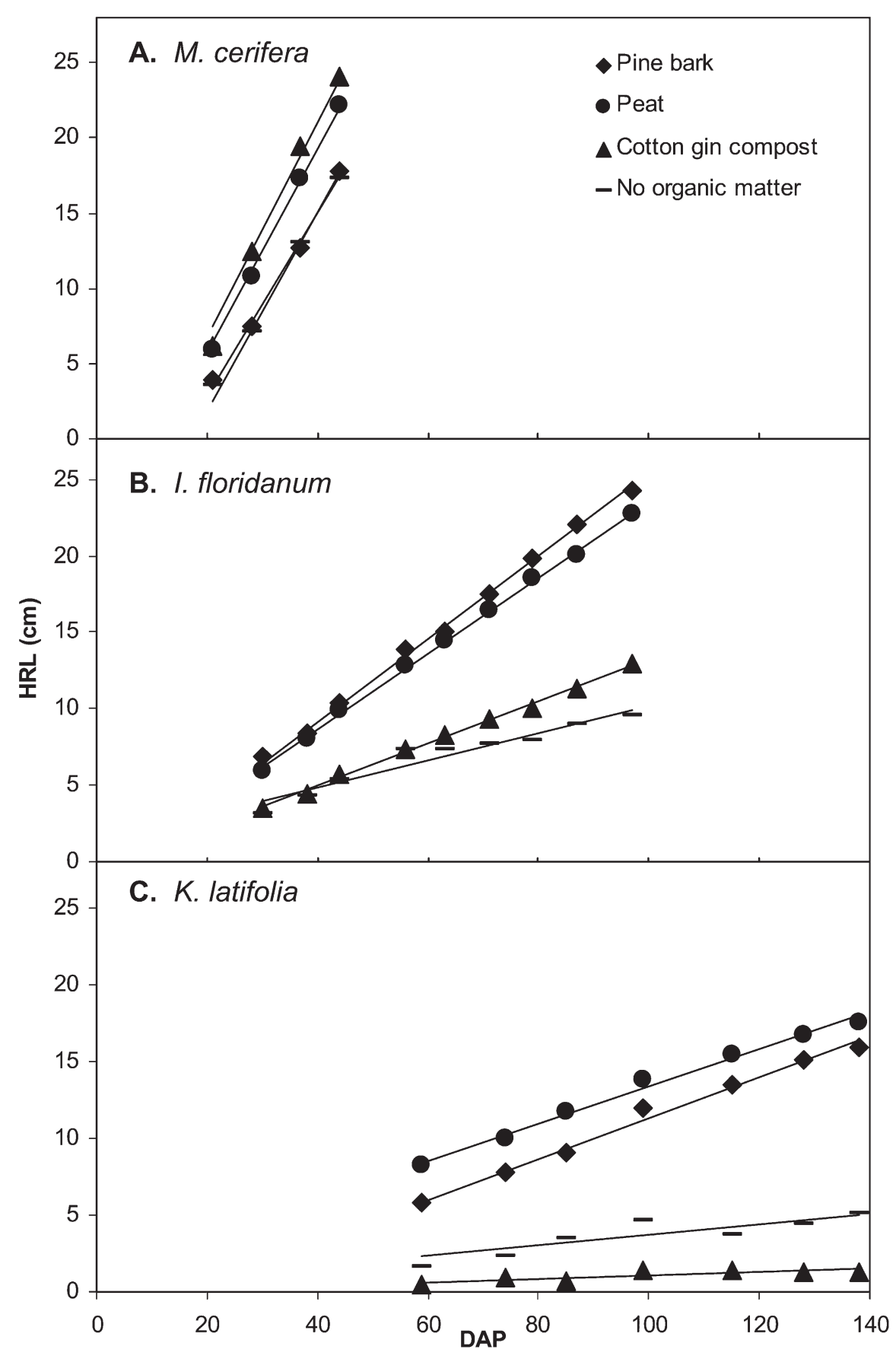

Fig. 2. Expt. 1. Effect of organic matter type on horizontal root length (length measured parallel to the ground, HRL) of (A) Morella cerifera measured 21 to $44 \mathrm{~d}$ after planting (DAP); (B) Illicium floridanum measured 30 to 97 DAP; and (C) Kalmia latifolia measured 59 to 138 DAP. Plants were planted 1 Mar. 2006, 6 June 2006, and 3 Jan. 2007, respectively, in a greenhouse at Auburn University in Auburn, AL.

0.54 to $0.7 \mathrm{~cm}$ per day, I. floridanum 0.04 to $0.3 \mathrm{~cm}$ per day, and K. latifolia 0.01 to $0.14 \mathrm{~cm}$ per day (Tables 1 and 3). Root dry weights or visual ratings generally agreed with HRL trends in both experiments. Variations between HRL and RDW (or inability to separate roots of species like $K$. latifolia from substrates) illustrate the importance of measuring HRL over time in addition to RDW to determine the rate of root growth as well as extent of root development laterally into the surrounding substrate. Observations from monitoring percent moisture in Expt. 2 additional shallow layer of pine straw on top of the mounded organic matter performed better under a uniform irrigation schedule than those planted at grade or using this technique with CGC, both of which also had the additional layer of pine straw (Guckenberger and Wright, 2008). The addition of pine straw, which is common in typical landscapes, may have minimized moisture loss in PB and P.

In both experiments, the rate of increase over time of the most rapidly growing lateral roots of $M$. cerifera was almost three times that of the fastest growing lateral roots of I. floridanum (Tables 1 and 3; Figs. 2 and 4). The most rapidly growing lateral roots, $M$. cerifera, increased at more than five times that of $K$. latifolia roots in PB, the most rapid increase of $K$. latifolia HRL in any substrate (Tables 1 and 3; Figs. 2 and 4). This demonstrates the varied speed of posttransplant root extension among the three species, whether planted in different seasons (Expt. 1) or at the same time of year (Expt. 2). Container-grown woody plants are described as easy- or difficult-to-transplant based on the time between transplanting and new root growth (Harris et al., 1996) and the ability of the roots to penetrate and extend into the surrounding soil to obtain water and nutrients from a larger area. The rate of increase in HRL for K. latifolia roots growing into PB was 10 times that of HRL of roots growing into NOM (Tables 1 and 3). Container-grown plants with coarse roots of larger diameters ( 0.9 to $1.5 \mathrm{~mm}$ ) may be better able to exert the growth pressure necessary to deform soil aggregates than plants with fine roots of smaller diameters $(0.2$ to $0.5 \mathrm{~mm})$ (Materechera et al., 1992). Thus, container-grown plants with fine roots such as $K$. latifolia may be classified as difficult to transplant as a result of slower posttransplant root growth and a lesser ability of roots to penetrate and extend into surroundings.

Root growth trends also may reflect the native habitats of the species. $M$. cerifera grows in a variety of conditions, particularly in full sun, under extremely wet or dry conditions, and in undesirable soils, so rapid root growth is a necessary means for survival. I. floridanum and $K$. latifolia are mostly found in more hospitable understory shade locations with thick litter layers that better hold nutrients and water, so speedy root growth may not be as essential for these species. K. latifolia may also be found in dense thickets in dry, high-exposure heath balds that form on rocky mountain tops and ridges in the central and southern Appalachians. From this, it seems that $K$. latifolia would be easy to transplant; however, this ability to thrive in high-exposure native habitats does not apply to horticultural transplanting applications. K. latifolia is a notoriously poor performer under any conditions, particularly in any other than cool, partly shaded, moist, well-drained, low-exposure locations (Wright, 2002). Although roots of $M$. cerifera rapidly extended laterally into the substrates and eventually grew into the soil 
A. M. cerifera - Expt. I
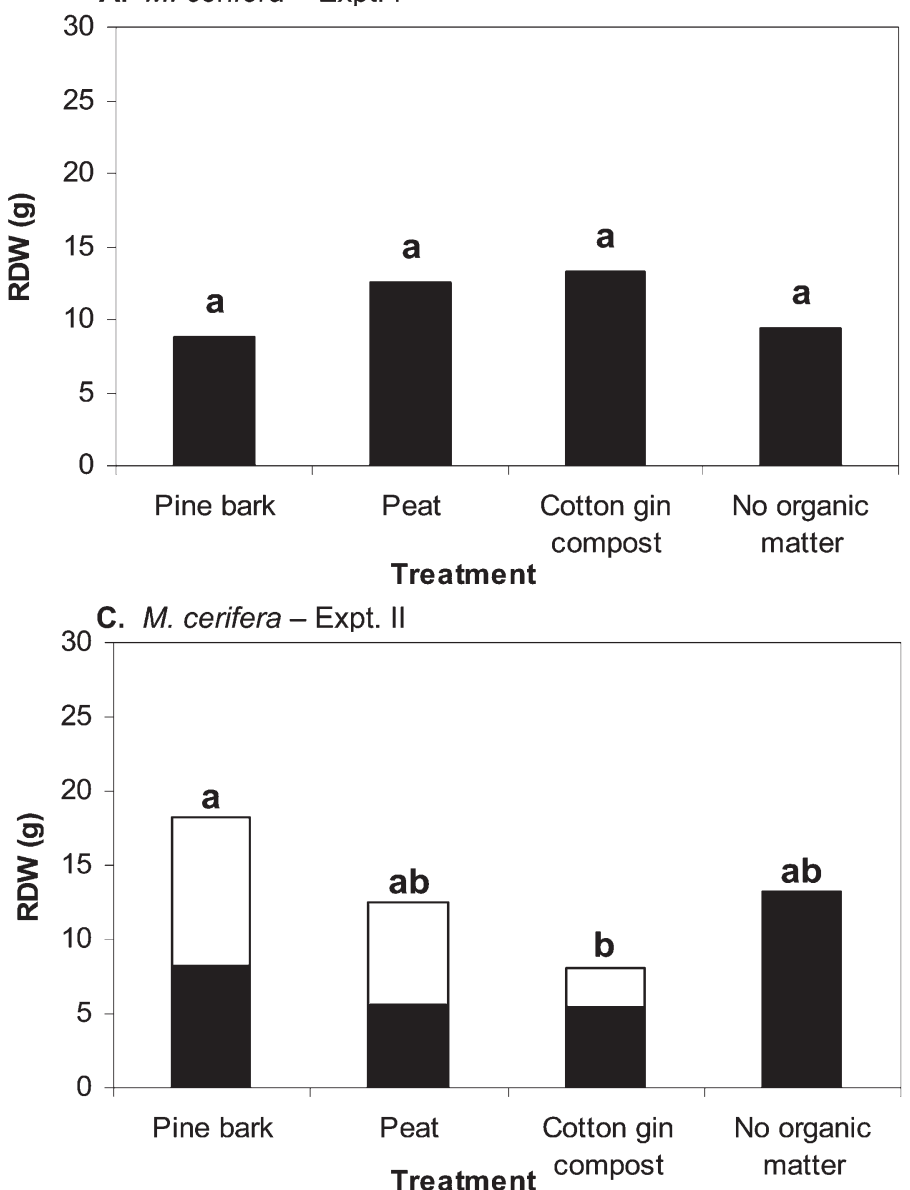

B. I. floridanum - Expt. I

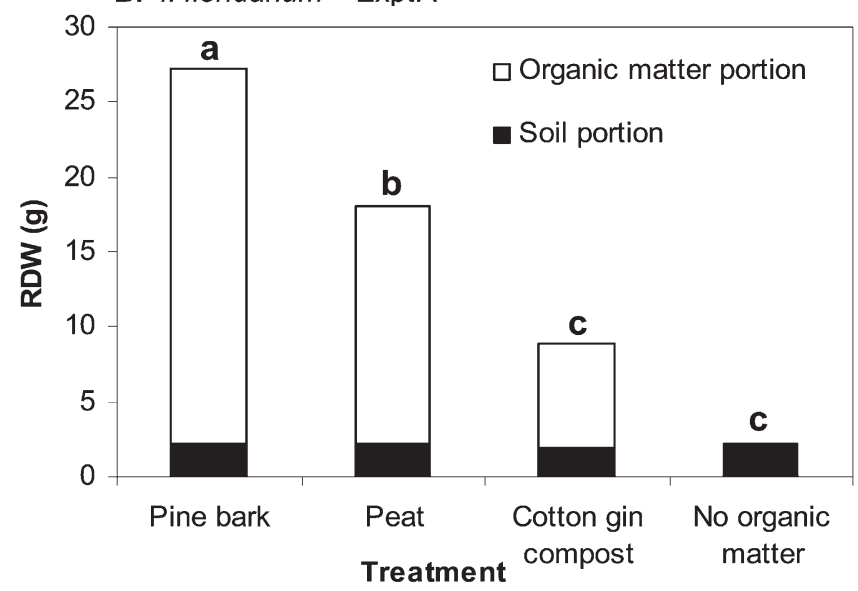

D. I. floridanum - Expt. II

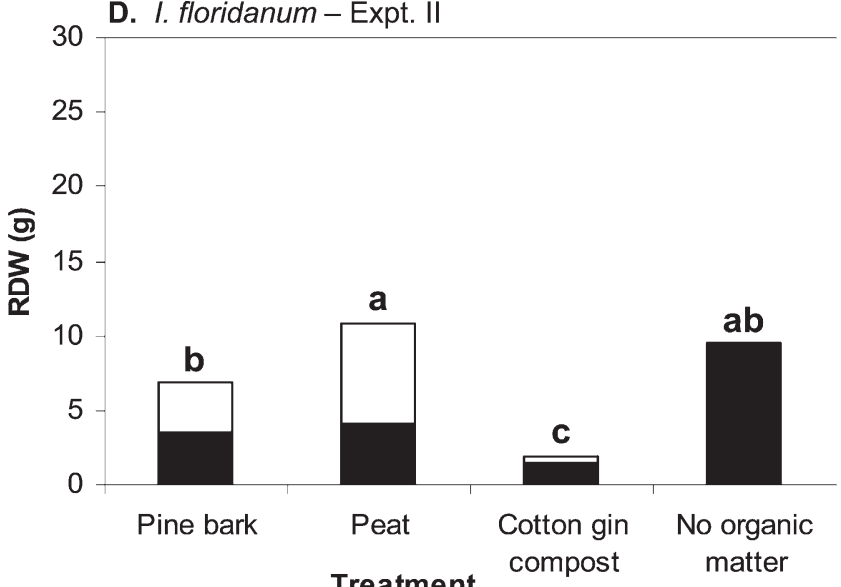

Fig. 3. Root dry weight (RDW) M. cerifera $(\mathbf{A}, \mathbf{C})$ and I. floridanum $(\mathbf{B}, \mathbf{D})$ from Expt. 1 (A-B) and Expt. 2 (C-D). Roots of B-D were divided into soil and organic matter portions in pine bark, peat, and cotton gin compost and washed separately to determine RDW. Lowercase letters denote means separation for total RDW ( $\mathrm{n}=5$ ) among substrates within species and experiment using PDIFF at $\alpha=0.05$ (SAS Institute, Inc., 2004). All plants were grown in Horhizotrons in a greenhouse in Auburn, AL. During Expt. 1, Morella cerifera and Illicium floridanum were grown 1 Mar. to 13 Apr. and 6 June to 6 Oct. 2006 , respectively. During Expt. 2, M. cerifera and I. floridanum were grown 19 June to 1 Aug. and 19 June to 6 Sept. 2007, respectively.

portion (Marvyn sandy loam) of each quadrant, in most quadrants, the majority of $M$. cerifera roots, particularly in the first few weeks, were in the layer of organic matter if present (visual observation). The majority of roots of I. floridanum and K. latifolia grew into the organic matter layer only over the entire measurement period (Table 2; Figs. 3B and $\mathrm{D}$; visual observation). Although no conclusions could be drawn from depth values associated with HRL measurements (data not shown), in future similar experiments, perhaps HRL could be measured separately for organic matter and soil portions within quadrants, potentially yielding more quantitative information about root distribution throughout the substrate profile. More root growth typically occurred in the organic matter layers, although Marvyn sandy loam is a well-drained soil with physical properties favorable for root growth (National Resources Conservation Service, U.S. Department of Agriculture, 1997), suggesting this technique would be particularly effective when applied to transplanting situations in the kinds of disturbed soils mentioned here.
Although other studies have shown an effect from $\mathrm{pH}$ (Wright et al., 2005), in this experiment, root growth did not correlate with $\mathrm{pH}$ because the $\mathrm{pH}$ values of solutions extracted from $\mathrm{CGC}$ and $\mathrm{PB}$ were similar (Table 4), but those substrates yielded very different HRL measurements (Tables 1 and 3 ). The soil was more alkaline than any other substrate (Table 4) and had little root growth, but physical properties and nutrient concentrations appeared to influence posttransplant root growth more than $\mathrm{pH}$. Also, because only one-fourth of each plant's root system was in a substrate, $\mathrm{pH}$ may not have affected growth of the whole plant, including roots. CGC had lower air space and higher waterholding capacity than the other types of organic matter, which may not have provided enough oxygen for root respiration. This, combined with high $\mathrm{EC}, \mathrm{NO}_{3}$, and salts, particularly sodium and potassium (Tables 4 and 5), indicates that CGC may not be the best organic matter to use when transplanting even slightly difficultto-transplant species (such as I. floridanum). Although CGC has been successful in horticultural production (Jackson et al., 2005), it may not be suitable for landscape purposes
Table 2. Visual ratings of $K$. latifolia root proliferation in four organic matter types (treatments) at experiment termination. ${ }^{2}$

\begin{tabular}{llc}
\hline & \multicolumn{2}{c}{ Visual rating $^{\mathrm{y}}$} \\
\cline { 2 - 3 } Treatment $^{\mathrm{x}}$ & Expt. 1 & Expt. 2 \\
\hline Pine bark & $2.8 \mathrm{~b}^{\mathrm{w}}$ & $2.2 \mathrm{a}$ \\
Peat & $4.8 \mathrm{a}$ & $2.0 \mathrm{a}$ \\
Cotton gin compost & $0.0 \mathrm{~d}$ & $0.3 \mathrm{~b}$ \\
No organic & $0.6 \mathrm{c}$ & $0.2 \mathrm{~b}$ \\
$\quad$ matter & & \\
\hline
\end{tabular}

"Plants were planted in Horhizotrons in Auburn, AL, on 3 Jan. (Expt. 1) and 18 June (Expt. 2) 2007 and grew to 136 and $127 \mathrm{~d}$ after planting, respectively.

${ }^{\mathrm{y}}$ Roots were evaluated visually using a scale of 0 to $5[0=$ no root growth; $1=10 \%$ of the quadrant was filled with roots; $2=20 \%$ of the quadrant was filled with roots; $3=30 \%$ of the quadrant was filled with roots; $4=40 \%$ of the quadrant was filled with roots; $5=50 \%$ of the quadrant was filled with roots (the most dense proliferation of any treatment)].

${ }^{x}$ Treatments were soil in bottom $10 \mathrm{~cm}$ and pine bark, peat, or cotton gin compost in upper $10 \mathrm{~cm}$ or $100 \%$ soil (no organic matter) in Horhizotron quadrants.

${ }^{w}$ Means separation within experiment using PDIFF at $\alpha=0.05$ (SAS Institute, Inc., 2004). 
Table 3. Expt. 2: Effect of organic matter type (treatment) on final horizontal root length $\left(\mathrm{HRL}^{\mathrm{z}}\right)$ of M. cerifera and I. floridanum (42 and $81 \mathrm{DAP}^{\mathrm{y}}$, respectively) growing in Horhizotrons in a greenhouse in Auburn, $\mathrm{AL}$, regression equations for change in HRL over time with corresponding $R^{2}$ term and significance of regression equation $(P$ value $)$, and significance of treatment main effects and interactions for HRL. ${ }^{x}$

\begin{tabular}{|c|c|c|c|c|}
\hline \multirow[b]{2}{*}{ Treatment ${ }^{\mathrm{w}}$} & \multicolumn{4}{|c|}{ M. cerifera } \\
\hline & $\overline{\mathrm{HRL}}(\mathrm{cm})$ & Equation $^{v}$ & $R^{2}$ & $P$ value \\
\hline Pine bark & $24.7 b^{u}$ & $y=0.69 x-3.68$ & 0.84 & $<0.0001$ \\
\hline Peat & $25.8 \mathrm{a}$ & $\mathrm{y}=0.69 x-1.87$ & 0.92 & $<0.0001$ \\
\hline Cotton gin compost & $19.2 \mathrm{c}$ & $y=0.54 x-3.60$ & 0.69 & $<0.0001$ \\
\hline No organic matter & $24.9 \mathrm{ab}$ & $y=0.68 x-2.93$ & 0.85 & $<0.0001$ \\
\hline Significance & $P$ value & & & \\
\hline Treatment & $<0.0001$ & & & \\
\hline DAP & $<0.0001$ & & & \\
\hline \multirow[t]{2}{*}{ Treatment $\times$ DAP } & $<0.0001$ & & & \\
\hline & \multicolumn{4}{|c|}{ I. floridanum } \\
\hline Treatment $^{\mathrm{w}}$ & HRL (cm) & Equation $^{v}$ & $R^{2}$ & $P$ value \\
\hline Pine bark & $16.8 \mathrm{~b}$ & $\mathrm{y}=0.27 \mathrm{x}-5.15$ & 0.81 & $<0.0001$ \\
\hline Peat & $19.5 \mathrm{a}$ & $\mathrm{y}=0.28 \mathrm{x}-3.19$ & 0.84 & $<0.0001$ \\
\hline Cotton gin compost & $3.0 \mathrm{~d}$ & $y=0.04 x-0.10$ & 0.11 & $<0.0001$ \\
\hline No organic matter & $12.7 \mathrm{c}$ & $y=0.19 x-3.10$ & 0.72 & $<0.0001$ \\
\hline Significance & $P$ value & & & \\
\hline Treatment & $<0.0001$ & & & \\
\hline DAP & $<0.0001$ & & & \\
\hline \multirow[t]{2}{*}{ Treatment $\times$ DAP } & $<0.0001$ & & & \\
\hline & \multicolumn{4}{|c|}{ K. latifolia } \\
\hline Treatment $^{\mathrm{w}}$ & HRL (cm) & Equation $^{\mathrm{v}}$ & $R^{2}$ & $P$ value \\
\hline Pine bark & $9.9 \mathrm{a}$ & $y=0.13 x-5.75$ & 0.27 & $<0.0001$ \\
\hline Peat & $6.7 \mathrm{~b}$ & $y=0.09 x-4.52$ & 0.12 & $<0.0001$ \\
\hline Cotton gin compost & $0.6 \mathrm{c}$ & $y=0.01 x-0.74$ & 0.06 & 0.0005 \\
\hline No organic matter & $0.8 \mathrm{c}$ & $\mathrm{y}=0.01 \mathrm{x}-0.51$ & 0.03 & 0.0014 \\
\hline Significance & $P$ value & & & \\
\hline Treatment & 0.0041 & & & \\
\hline DAP & $<0.0001$ & & & \\
\hline Treatment $\times$ DAP & $<0.0001$ & & & \\
\hline
\end{tabular}

${ }^{\mathrm{z}} \mathrm{HRL}=$ root length measured parallel to the ground.

${ }^{\mathrm{y}} \mathrm{DAP}=$ days after planting in Horhizotron (Wright and Wright, 2004).

${ }^{\mathrm{x}}$ M. cerifera were grown 19 June to 1 Aug. 2007, I. floridanum were grown 19 June to 6 Sept. 2007, and K. latifolia were grown 19 June to 23 Oct. 2007.

${ }^{\text {w }}$ Treatments were soil in bottom $10 \mathrm{~cm}$ and pine bark, peat, or cotton gin compost in upper $10 \mathrm{~cm}$ or $100 \%$ soil (no organic matter) in Horhizotron quadrants.

$\mathrm{v} y=$ HRL, $\mathrm{x}=$ DAP.

"Lowercase letters denote mean separation $(\mathrm{n}=50)$ among substrates within species by PDIFF at $\alpha=0.05$ (SAS Institute, Inc., 2004).

because the salts did not leach as readily in this experiment as in the daily watering scenarios of container production (Jackson et al., 2005). There was little decline in EC and nutrient concentrations over the course of the experiments. Species with fine root systems (such as $K$. latifolia) are particularly vulnerable to the high salt levels that may be common in composts (Sæbø and Ferrini, 2006). They are also susceptible to mechanical impedance in the soil (Materechera et al., 1992); thus, low bulk density can improve posttransplant root growth. Bulk density was generally lowest and chemical properties more favorable for $\mathrm{PB}$ and $\mathrm{P}$ (Tables 4 and 5), in which the greatest HRL and generally the highest RDW or visual ratings were found for all species (Tables 1-3; Figs. 2-4).

Although mature roots are responsible for the majority of nutrient and water uptake, thinner, unsuberized new roots still absorb water at nearly five times the rate of older roots (Kramer and Bullock, 1966). This emphasizes the need for speedy fine root proliferation on transplanting to quickly absorb water and decrease plant moisture stress, which should aid the growth of more roots that
Table 4. Initial and final $\mathrm{pH}$ and electrical conductivity $(\mathrm{EC})^{\mathrm{z}}$ of substrate solutions.

\begin{tabular}{|c|c|c|c|c|}
\hline \multirow[b]{3}{*}{ Substrate } & \multicolumn{4}{|c|}{ Expt. 1} \\
\hline & \multicolumn{2}{|c|}{$\mathrm{pH}$} & \multicolumn{2}{|c|}{ EC } \\
\hline & $\overline{\text { Initial }}$ & Final & Initial & Final \\
\hline Pine bark & $6.4 \mathrm{~b}^{\mathrm{y}}$ & $6.3 \mathrm{~b}$ & $0.1 \mathrm{~b}$ & $0.2 \mathrm{~b}$ \\
\hline Peat & $3.9 \mathrm{~d}$ & $3.9 \mathrm{c}$ & $0.2 \mathrm{~b}$ & $0.2 \mathrm{~b}$ \\
\hline $\begin{array}{l}\text { Cotton gin } \\
\text { compost }\end{array}$ & $5.8 \mathrm{c}$ & $6.5 \mathrm{~b}$ & $2.7 \mathrm{a}$ & $0.6 \mathrm{a}$ \\
\hline \multirow[t]{3}{*}{$\begin{array}{l}\text { No organic } \\
\text { matter }\end{array}$} & $7.1 \mathrm{a}$ & $6.8 \mathrm{a}$ & $0.1 \mathrm{~b}$ & $0.2 \mathrm{~b}$ \\
\hline & \multicolumn{4}{|c|}{ Expt. 2} \\
\hline & \multicolumn{2}{|c|}{$\mathrm{pH}$} & \multicolumn{2}{|c|}{ EC } \\
\hline Substrate & Initial & $\overline{\text { Final }}$ & $\overline{\text { Initial }}$ & Final \\
\hline Pine bark & $4.7 \mathrm{c}$ & $6.5 \mathrm{a}$ & $0.3 \mathrm{~b}$ & 0.2 \\
\hline Peat & $3.8 \mathrm{~d}$ & $5.7 \mathrm{~b}$ & $0.2 \mathrm{~b}$ & 0.3 \\
\hline $\begin{array}{l}\text { Cotton gin } \\
\text { compost }\end{array}$ & $5.2 \mathrm{~b}$ & $5.7 \mathrm{~b}$ & $1.9 \mathrm{a}$ & 1.8 \\
\hline $\begin{array}{l}\text { No organic } \\
\text { matter }\end{array}$ & $7.1 \mathrm{a}$ & $7.0 \mathrm{a}$ & $0.3 \mathrm{~b}$ & 0.5 \\
\hline
\end{tabular}

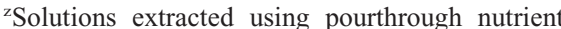
extraction procedure (Wright, 1986).

${ }^{\mathrm{y}}$ Means separated using PDIFF at $\alpha=0.05$ (SAS Institute, Inc., 2004).

aging proliferation of roots in this layer and upper soil horizons. Plants in cultivation have less than half the root:shoot ratio of those in natural areas (Robinson et al., 2003), possibly because they lack a natural litter layer and may be watered and fertilized regularly. This planting practice may not be as important (but is in no way detrimental) for easy-to-transplant species like $M$. cerifera that quickly grow roots after transplanting, but may be very important for species like $K$. latifolia that are more sensitive to the posttransplant environment in which they must grow roots and establish themselves. Using this technique to increase posttransplant root growth may not only improve initial success after transplanting, but in field studies, it also appears to improve long-term survival and promote superior root growth into the surrounding soil compared with traditional planting practices (unpublished data). Finally, demonstrating success of techniques such as above-grade planting that contribute to establishment and survival of native landscape shrubs could encourage increased acceptance and use of these species in urban landscapes.

Table 5. Concentrations (ppm) of mineral nutrients, ammonium-nitrogen, and nitrate-nitrogen of saturated extract ${ }^{z}$ of substrates or soil.

\begin{tabular}{|c|c|c|c|c|c|c|c|}
\hline & Calcium & Potassium & Magnesium & Phosphorus & Aluminum & Boron & Zinc \\
\hline Pine bark & $13.7 b^{y}$ & $64.4 \mathrm{~b}$ & $16.8 \mathrm{~b}$ & $7.4 \mathrm{~b}$ & $26.3 \mathrm{a}$ & $0.3 \mathrm{~b}$ & $0.5 \mathrm{a}$ \\
\hline Peat & $31.0 \mathrm{~b}$ & $0.6 \mathrm{c}$ & $0.4 \mathrm{~d}$ & $0.2 \mathrm{c}$ & $0.1 \mathrm{~b}$ & $<0.1 \mathrm{c}$ & $0.1 \mathrm{~b}$ \\
\hline $\begin{array}{l}\text { Cotton gin } \\
\text { compost }\end{array}$ & $306.3 \mathrm{a}$ & $98.7 \mathrm{a}$ & $48.4 \mathrm{a}$ & $24.2 \mathrm{a}$ & $0.3 \mathrm{~b}$ & $0.5 \mathrm{a}$ & $<0.1 \mathrm{c}$ \\
\hline \multirow{2}{*}{$\begin{array}{l}\text { No organic } \\
\text { matter }\end{array}$} & $1.1 \mathrm{~b}$ & $2.4 \mathrm{c}$ & $2.9 \mathrm{c}$ & $0.2 \mathrm{c}$ & $0.1 \mathrm{~b}$ & $<0.1 \mathrm{c}$ & $<0.1 \mathrm{c}$ \\
\hline & Copper & Iron & Manganese & Sodium & $\mathrm{NH}_{4}-\mathrm{N}$ & $\mathrm{NO}_{3}-\mathrm{N}$ & \\
\hline Pine bark & 0.2 & $1.1 \mathrm{~b}$ & $1.8 \mathrm{a}$ & $2.2 \mathrm{~b}$ & $0.1 \mathrm{c}$ & $4.2 \mathrm{~b}$ & \\
\hline Peat & 0.3 & $<0.1 \mathrm{c}$ & $<0.1 \mathrm{~b}$ & $2.3 \mathrm{~b}$ & $3.9 \mathrm{a}$ & $0.9 \mathrm{~b}$ & \\
\hline $\begin{array}{l}\text { Cotton gin } \\
\text { compost }\end{array}$ & 0.2 & $<0.1 \mathrm{c}$ & $<0.1 \mathrm{~b}$ & $3.6 \mathrm{a}$ & $1.1 \mathrm{~b}$ & $518.5 \mathrm{a}$ & \\
\hline $\begin{array}{l}\text { No organic } \\
\text { matter }\end{array}$ & 0.1 & $1.9 \mathrm{a}$ & $<0.1 \mathrm{~b}$ & $3.3 \mathrm{a}$ & $0.1 \mathrm{c}$ & $7.7 \mathrm{~b}$ & \\
\hline
\end{tabular}

${ }^{2}$ Soil and substrate analysis by saturated extraction, Auburn University Soil Testing Laboratory, Auburn, AL.

${ }^{y}$ Means separated using PDIFF at $\alpha=0.05$ (SAS Institute, Inc., 2004). 


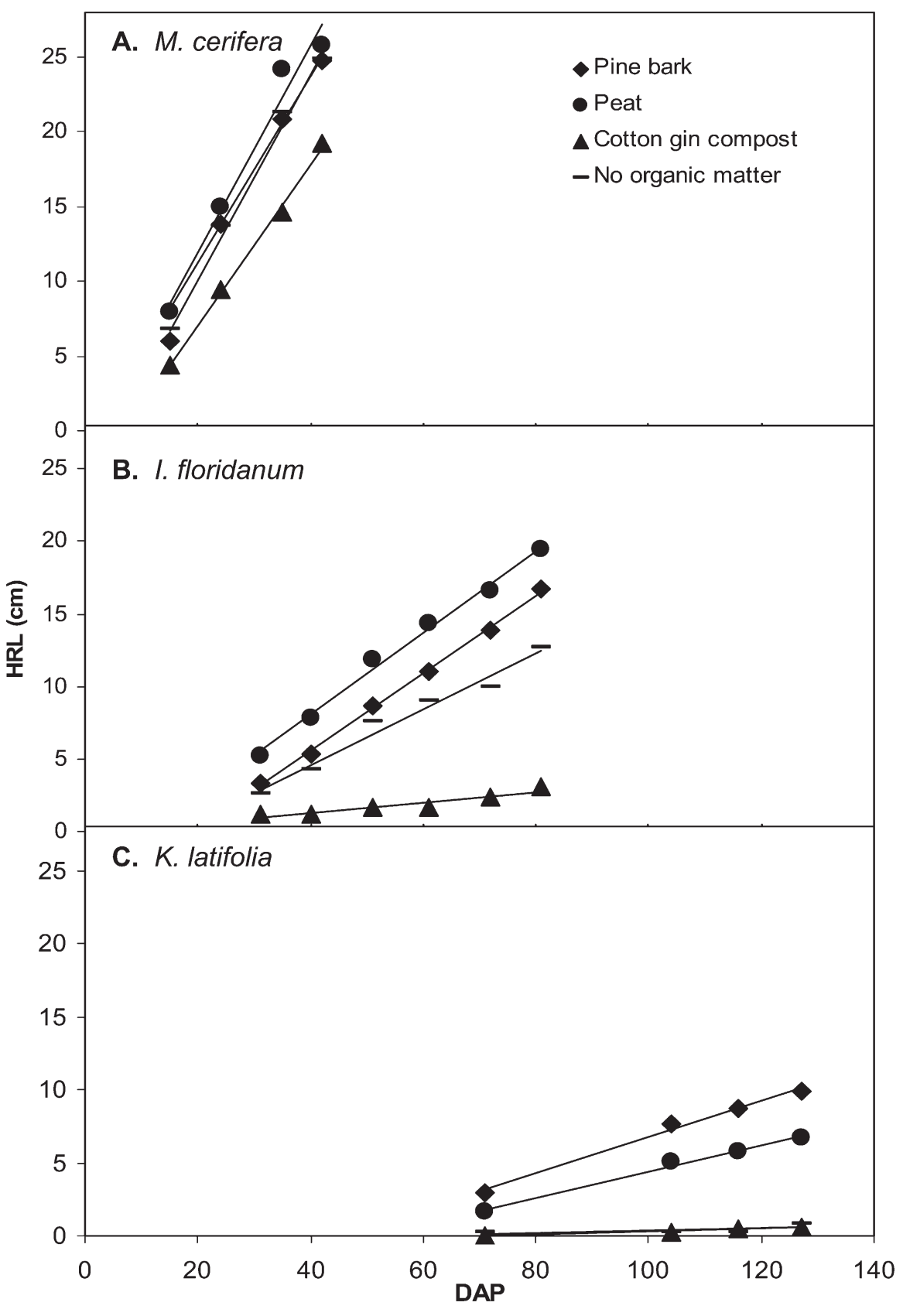

Fig. 4. Expt. 2. Effect of organic matter type on horizontal root length (length measured parallel to the ground, HRL) of (A) M. cerifera measured 24 to $42 \mathrm{~d}$ after planting (DAP); (B) I. floridanum measured 31 to 81 DAP; and (C) K. latifolia measured 71 to 127 DAP. Plants were planted 19 June 2007 in a greenhouse at Auburn University in Auburn, AL.

\section{Literature Cited}

Arnold, M.A., G.V. McDonald, and D.L. Bryan. 2005. Planting depth and mulch thickness affect establishment of green ash and bougainvillea raintree. J. Arboricult. 31:163167.

Craul, P.J. 1985. A description of urban soils and their desired characteristics. J. Arboricult. 11:330-339.

Day, S.D., N.L. Bassuk, and H. van Es. 1995. Effects of four compaction remediation methods for landscape trees on soil aeration, mechanical impedance, and tree establishment. J. Environ. Hort. 13:64-71. physiology of two native shrub species. HortScience 43:602. (abstr.).

Harris, R.W., P. Knight, and J. Fanelli. 1996. Fall transplanting improves establishment of balled and burlapped fringe tree (Chionanthus virginicus L.). HortScience 31:1143-1145.

Heiskanen, J. and R. Rikala. 2000. Effect of peatbased container media on establishment of Scots pine, Norway spruce, and silver birch seedlings after transplanting in contrasting water conditions. Scandinavian J. Environ. For. Res. 15:49-57.

Jackson, B.E., A.N. Wright, J.L. Sibley, and J.M. Kemble. 2005. Cotton gin compost as a substrate component in container production of nursery crops. J. Environ. Hort. 23:118-122.

Kramer, P.J. and H.C. Bullock. 1966. Seasonal variations in the proportions of suberized and unsuberized roots of trees in relation to the absorption of water. Amer. J. Bot. 53:200204.

Materechera, S.A., A.M. Alston, J.M. Kirby, and A.R. Dexter. 1992. Influence of root diameter on the penetration of seminal roots into a compacted subsoil. Plant Soil 144:297-303.

Natural Resources Conservation Service, U.S. Department of Agriculture. 1997. Official soil series descriptions. 8 Jan. 2008. <http://ortho. ftw.nrcs.usda.gov/osd/dat/M/MARVYN.html>.

Perry, T.O. 1982. The ecology of tree roots and the practical significance thereof. J. Arboricult. 8:197-211.

Robinson, D., A. Hodge, and A. Fitter. 2003. Constraints on the form and function of root systems, p. 1-31. In: de Kroon, H., and E.J.W. Visser (eds.). Root ecology. Springer-Verlag, Berlin, Germany.

Sæbø, A. and F. Ferrini. 2006. The use of composts in urban green areas-A review for practical application. Urban For. \& Urban Gardening 4:159-169.

SAS Institute, Inc. 2004. SAS user's guide. Release 9.1. SAS Institute, Inc., Cary, NC.

Smalley, T.J. and C.B. Wood. 1995. Effect of backfill amendments on growth of red maple. J. Arboricult. 21:247-249.

Southeast Exotic Pest Plant Council. 2008. Landscaping with native plants. 16 Dec. 2008. <http:// www.se-eppc.org/pubs/landscape.html>.

Watson, G.W., G. Kupkowski, and K.G. von der Heide-Spravka. 1993. Influence of backfill soil amendments on establishment of containergrown shrubs. HortTechnology 3:188-189.

Wright, R.D. 1986. The pour-through nutrient extraction procedure. HortScience 21:227229.

Wright, A.N. 2002. The physiology of landscape establishment of Kalmia latifolia, North Carolina State Univ., Raleigh, NC. PhD Diss. Abstr. 05102002-135147.

Wright, A.N. and R.D. Wright. 2004. The Horhizotron $^{\mathrm{TM}}$ : A new instrument for measuring root growth. HorTechnology 14:560-563.

Wright, A.N., R.D. Wright, B.E. Jackson, and J.F Browder. 2005. Effect of rhizosphere $\mathrm{pH}$ on root growth of two landscape species. HortScience 40:1060.

Wright, A.N., R.D. Wright, B.E. Jackson, and J.F. Browder. 2007. Effect of backfill composition on post-transplant root growth of Kalmia latifolia L. J. Environ. Hort. 25:145-149. 